\title{
UJI EFEKTIVITAS PUPUK ORGANONITROFOS DAN KOMBINASINYA DENGAN PUPUK ANORGANIK TERHADAP PERTUMBUHAN, SERAPAN HARA, DAN PRODUKSI TANAMAN KACANG HIJAU (Phaseolus radiatus L.) PADA TANAH ULTISOL NATAR
}

\author{
Untung Sakinata, Yafizham, Jamalam Lumbanraja \& Setyo Dwi Utomo \\ Jurusan Agroteknologi, Fakultas Pertanian Universitas Lampung \\ J1. Prof. Dr. Soemantri Brodjonegoro no. 1 Bandar Lampung 35145 \\ Email : untung.sakinata@yahoo.com
}

\begin{abstract}
ABSTRAK
Permasalahan dalam pengelolaan tanaman kacang hijau di tingkat petani antara lain produktivitas yang masih rendah. Intensifikasi pertanian merupakan salah satu cara yang tepat dilakukan untuk meningkatkan hasil pertanian dengan mengoptimalkan lahan yang sudah ada diantaranya dengan pemupukan. Pupuk Organonitrofos merupakan pupuk organik baru yang memerlukan pengujian keefektivitasannya terhadap tanaman. Penelitian ini bertujuan untuk mengetahui dosis terbaik dalam meningkatkan pertumbuhan, serapan hara, dan produksi tanaman kacang hijau. Selain itu, untuk mengetahui efektivitas pupuk Organonitrofos dan kombinasinya dengan pupuk anorganik secara agronomis pada tanaman kacang hijau. Penelitian ini dilaksanakan di Desa Muara Putih Kecamatan Natar Lampung Selatan dari bulan Desember $2012-$ April 2013. Penelitian ini disusun dalam rancangan acak kelompok (RAK) dengan 6 (enam) perlakuan yaitu A (tanpa pupuk); B (NPK rekomendasi); C (3/4 NPK rekomendasi+Organonitrofos $\left.500 \mathrm{~kg} \mathrm{ha}^{-1}\right) ; \mathrm{D}\left(1 / 2 \mathrm{NPK}\right.$ rekomendasi+Organonitrofos $\left.1.000 \mathrm{~kg} \mathrm{ha}^{-1}\right)$; E ( $1 / 4$ NPK rekomendasi+Organonitrofos $2.000 \mathrm{~kg} \mathrm{ha}^{-1}$ ); dan F (Organonitrofos $3.000 \mathrm{~kg} \mathrm{ha}^{-1}$ ) dengan tiga kali ulangan. Plot percobaan dikelompokkan berdasarkan ulangan dan topografi lahan. Data yang dihasilkan di rata-rata berdasarkan kelompoknya, kemudian diuji homogenitas dengan uji Barllet dan aditivitas dengan uji Tukey. Selanjutnya dianalisis dengan sidik ragam dan dilanjutkan dengan uji BNT pada taraf 5\%. Hasil penelitian ini menunjukkan bahwa perlakuan D (1/2 NPK rekomendasi+Organonitrofos $1.000 \mathrm{~kg} \mathrm{ha}^{-1}$ ) memberikan hasil lebih baik dan lebih efektif secara agronomis dalam meningkatkan pertumbuhan, serapan hara NPK, dan produksi tanaman kacang hijau dibandingkan dengan perlakuan lainnya. Hal tersebut menjadikan kombinasi perlakuan ini lebih dianjurkan untuk diterapkan petani karena lebih berpotensi dalam meningkatkan produktivitas kacang hijau serta mampu memelihara kualitas lahan.
\end{abstract}

Kata kunci: Kacang Hijau, organonitrofos, pupuk anorganik, Ultisol.

\section{PENDAHULUAN}

Kacang hijau (Phaseolus radiatus L.) merupakan salah satu tanaman pangan yang berpotensi untuk dikembangkan secara intensif. Permintaan kacang hijau dalam negeri makin meningkat dari tahun ke tahun. Berdasarkan data Direktorat Budidaya Aneka Kacang dan Umbi (2013), permintaan kacang hijau pada lima tahun terakhir berturut-turut sebesar 269 ton, 284 ton, 263 ton, 304 ton, dan 314 ton. Akan tetapi, tanaman ini masih kurang mendapatkan perhatian petani untuk dibudidayakan. Permasalahan dalam pengelolaan tanaman kacang hijau di tingkat petani antara lain produktivitas masih rendah. Berdasarkan Biro Pusat Statistik (2014), produktivitas kacang hijau di Provinsi Lampung pada lima tahun terakhir masih sekitar 0,89 $\mathrm{t}$ ha $^{-1}$, sedangkan hasil di tingkat percobaan dapat mencapai 1,0-1,8 t ha-1 (Balitkabi, 2012). Hal ini menunjukkan bahwa produktivitas kacang hijau di Lampung masih mungkin untuk ditingkatkan.

Produktivitas kacang hijau dapat ditingkatkan dengan cara ekstensifikasi dan intensifikasi pertanian. Namun, pengembangan dengan cara ekstensifikasi sudah kecil kemungkinannya mengingat semakin terbatasnya lahan pertanian. Maka peningkatan produktivitas diusahakan dengan cara intensifikasi. Pemupukan merupakan salah satu bentuk kegiatan intensifikasi yang perlu dilakukan dalam sistem budidaya tanaman khususnya untuk tanaman kacang hijau. Pada umumnya pupuk yang digunakan dalam budidaya kacang hijau adalah pupuk anorganik. Lingga dan Marsono (2001) menyatakan bahwa pemberian pupuk anorganik 
tanpa diimbangi dengan penggunaan pupuk organik dapat menurunkan sifat fisik, kimia, dan biologi tanah. Oleh karena itu, diperlukan pupuk organik yang mampu menyediakan unsur hara yang memadai dalam usaha pertanian seperti kacang hijau. Atman (2007) menyatakan bahwa dalam sistem budidaya kacang hijau bahan organik berupa pupuk kandang diperlukan cukup banyak berkisar antara 15-20 $\mathrm{t} \mathrm{ha}^{-1}$.

Salah satu pupuk organik yang dapat digunakan untuk memperbaiki kesuburan tanah adalah pupuk Organonitrofos. Pupuk Organonitrofos terbentuk dari pengomposan kotoran sapi segar dan batuan fosfat alam (Nugroho dkk., 2012). Didalamnya juga ditambahkan mikroorganisme pelarut $\mathrm{P}$ (Aspergillus niger dan Pseudomonas fluorescens) dan mikroorganisme penambat N (Azotobacter sp. dan Azospirillum sp.) (Nugroho dkk., 2013) yang diinkubasikan dalam waktu cukup dan digranulasi menjadi pupuk berbentuk granul (butiran). Deviana (2014) menyatakan bahwa aplikasi kombinasi pupuk Organonitrofos dan kombinasinya dengan pupuk kimia dengan dosis urea $150 \mathrm{~kg} \mathrm{ha}^{-1}$, SP$3650 \mathrm{~kg} \mathrm{ha}^{-1}, \mathrm{KCl} 100 \mathrm{~kg} \mathrm{ha}^{-1}$, Organonitrofos $1.000 \mathrm{~kg}$ $\mathrm{ha}^{-1}$ mampu meningkatkan pertumbuhan yaitu tinggi tanaman, produksi meliputi bobot pipilan kering dan bobot berangasan dengan perbandingan dengan kontrol berturut-turut sebesar 23,6 cm; 0,77 ton ha ${ }^{-1}$; dan 1,65 ton $\mathrm{ha}^{-1}$; dan serapan hara NPK total dengan perbandingan dengan kontrol berturut-turut sebesar $147,3 \mathrm{~kg} \mathrm{ha}^{-1}, 22,4 \mathrm{~kg} \mathrm{ha}^{-1}$, dan $15,0 \mathrm{~kg} \mathrm{ha}^{-1}$, serta perlakuan ini juga memberikan nilai RAE paling tinggi dengan nilai $25 \%$ lebih tinggi daripada hasil pupuk rekomendasi pada tanaman jagung. Pupuk Organonitrofos diharapkan dapat menjadi pupuk organik alternatif dan sebagai substitusi penggunaan pupuk anorganik. Penelitian ini bertujuan untuk mengetahui dosis kombinasi pupuk Organonitrofos dengan pupuk anorganik terbaik dalam meningkatkan pertumbuhan, serapan hara, dan produksi tanaman kacang hijau dan untuk mengetahui efektivitas pupuk Organonitrofos dan kombinasinya dengan pupuk anorganik secara agronomis pada tanaman kacang hijau.

\section{BAHAN DAN METODE}

Penelitian ini dilaksanakan di Kebun Percobaan Fakultas Pertanian Universitas Lampung Desa Muara Putih Kecamatan Natar Lampung Selatan dengan titik koordinat $05^{\circ} 15^{\prime} 51^{\prime \prime}$ LS dan $105^{\circ} 13^{\prime} 33^{\prime \prime}$ BT dari bulan Desember 2012-April 2013. Analisis tanah dan tanaman dilakukan di Laboratorium Ilmu Tanah Fakultas Pertanian Universitas Lampung pada bulan Maret 2013. Penelitian ini menggunakan Rancangan Acak Kelompok
(RAK) terdiri dari 6 perlakuan dengan 3 ulangan. Perlakuan berdasarkan dosis pupuk yang diberikan yaitu A (tanpa pupuk); B (NPK rekomendasi); C (3/4 NPK rekomendasi+Organonitrofos $\left.500 \mathrm{~kg} \mathrm{ha}^{-1}\right) ; \mathrm{D}(1 / 2 \mathrm{NPK}$ rekomendasi+Organonitrofos $\left.1.000 \mathrm{~kg} \quad \mathrm{ha}^{-1}\right) ; \mathrm{E}(1 / 4$ NPK rekomendasi+Organonitrofos $2.000 \mathrm{~kg} \mathrm{ha}^{-1}$ ); dan $\mathrm{F}$ (Organonitrofos $3.000 \mathrm{~kg} \mathrm{ha}^{-1}$ ). Petak percobaan berukuran 4 × $8 \mathrm{~m}$ dengan jarak antar petak $1 \mathrm{~m}$.

Benih kacang hijau ditanam dengan jarak $40 \mathrm{~cm}$ x $15 \mathrm{~cm}$. Aplikasi pupuk urea dilakukan sebanyak dua kali yaitu aplikasi pertama (setengah dosis) pada 7 hst bersamaan dengan pupuk Organonitrofos, SP-36, dan $\mathrm{KCl}$ yang diberikan sekaligus secara larikan. Aplikasi kedua (sisa setengah dosis) dilakukan 22 hst. Pemanenan dilakukan sebanyak dua kali yaitu pada umur 57 hst dan 61 hst. Pengeringan polong dilakukan dengan sinar matahari dengan menjemur diatas karung. Sampel tanaman yang diambil adalah seluruh bagian atas tanaman. Setelah kacang hijau dipanen lalu dibersihkan dan dicuci hingga tidak ada tanah yang ikut menempel pada tanaman sampel.

Pengamatan dilakukan terhadap fase vegetatif yaitu tinggi tanaman. Pada fase generatif pengamatan dilakuan pada jumlah polong, serapan hara (berangkasan tanaman dan buah), dan produksi yang dikonversi dalam satuan $\mathrm{kg} \mathrm{ha}^{-1}$. Selain itu, pengamatan juga dilakukan terhadap uji efektivitas Organonitrofos. Uji efektivitas pupuk dihitung menggunakan RAE dengan membandingkan antara kenaikan hasil karena penggunaan pupuk Organonitrofos dengan kenaikan hasil akibat penggunaan pupuk anorganik dikalikan $100 \%$ (Suswono, 2011).

\section{HASIL DAN PEMBAHASAN}

Hasil penelitian menunjukkan bahwa pertumbuhan tanaman kacang hijau terus mengalami peningkatan dari tiap minggunya yang ditandai oleh peningkatan tinggi tanaman (Gambar 1). Pada Gambar 1 terlihat bahwa minggu ke-2 dan ke-3 perlakuan pemupukan belum berpengaruh terhadap tinggi tanaman kacang hijau, namun pada minggu ke-4 dan ke-5 kombinasi pemupukan telah menunjukkan pengaruh nyata (Tabel 1). Hal ini disebabkan karena sifat pupuk Organonitrofos sebagai pupuk organik yang lambat tersedia bagi tanaman. Mulyati dkk., (2007) menyatakan bahwa pupuk organik dapat diserap tanaman jika telah mengalami proses perubahan bentuk dari $\mathrm{N}$-organik menjadi $\mathrm{N}$-anorganik melalui proses amonifikasi dan nitrifikasi. Akan tetapi, berdasarkan deskripsi varietas Vima-1 yang digunakan, tinggi tanaman tersebut masih jauh lebih rendah dibandingkan dengan tinggi tanaman 


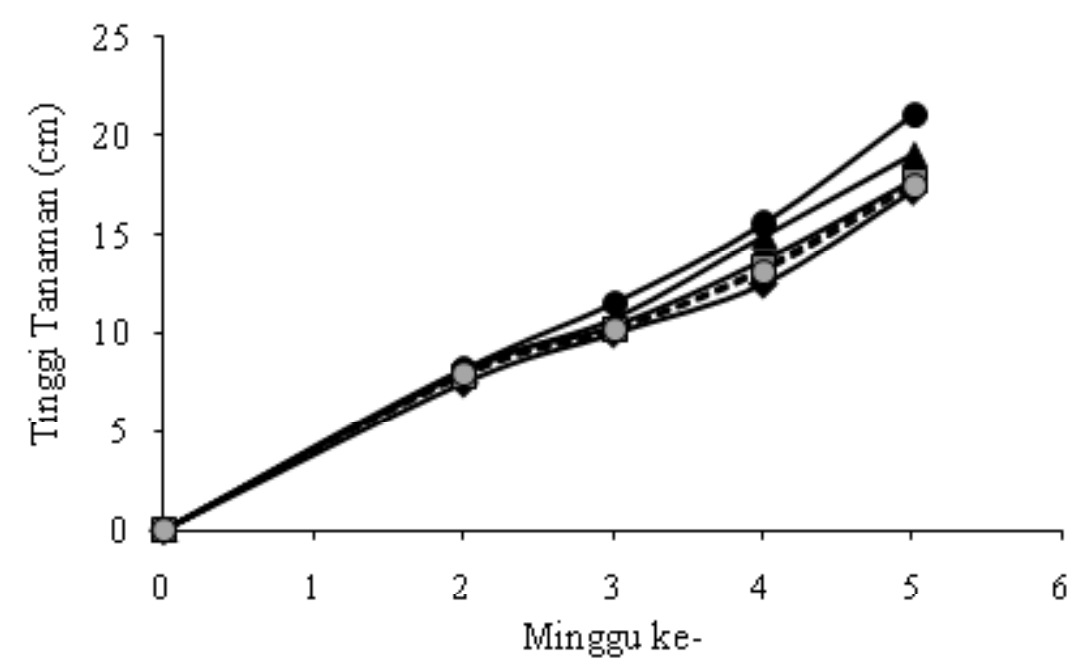

Gambar 1. Perkembangan tinggi tanaman akibat pengaruh pemupukan Organonitrofos dan kombinasinya dengan pupuk anorganik. A (—) = Kontrol, B (一-) = urea $50 \mathrm{~kg} \mathrm{ha}^{-1}, \mathrm{SP}-3660 \mathrm{~kg} \mathrm{ha}^{-1}, \mathrm{KCl} 50 \mathrm{~kg} \mathrm{ha}^{-1}$, $\mathrm{C}(\longrightarrow-)=$ urea $37,5 \mathrm{~kg} \mathrm{ha}^{-1}$, SP-36 $45 \mathrm{~kg} \mathrm{ha}^{-1}, \mathrm{KCl} 37,5 \mathrm{~kg} \mathrm{ha}^{-1}, 500$ Organonitrofos $\mathrm{kg} \mathrm{ha}^{-1}$, $\mathrm{D}(\longrightarrow)$ = urea $25 \mathrm{~kg} \mathrm{ha}^{-1}$, SP-36 $30 \mathrm{~kg} \mathrm{ha}^{-1}, \mathrm{KCl} 25 \mathrm{~kg} \mathrm{ha}^{-1}$, Organonitrofos $1.000 \mathrm{~kg} \mathrm{ha}^{-1}$, $\mathrm{E}(-\square--)=$ urea 12,5 $\mathrm{kg} \mathrm{ha}^{-1}$, SP-36 $15 \mathrm{~kg} \mathrm{ha}^{-1}, \mathrm{KCl} 12,5 \mathrm{~kg} \mathrm{ha}^{-1}$, Organonitrofos $2.000 \mathrm{~kg} \mathrm{ha}^{-1}$, $\mathrm{F}(-\infty--)=$ Organonitrofos $3.000 \mathrm{~kg} \mathrm{ha}^{-1}$.

pada kondisi optimal yang mampu mencapai $53 \mathrm{~cm}$ (Balitkabi, 2012). Hal ini terjadi karena kondisi iklim saat pertanaman hingga panen merupakan musim hujan dengan intensitas tinggi. Hal tersebut menyebabkan aliran permukaan tinggi sehingga ketersediaan unsur hara bagi tanaman menjadi berkurang. Hal ini sejalan dengan penelitian Zebua, dkk., (2012) bahwa perubahan iklim berpengaruh besar pada tinggi tanaman kacang hijau varietas Vima-1.

Peningkatan bobot berangkas tanaman kacang hijau tertinggi terlihat pada kombinasi pupuk Organonitrofos dengan pupuk anorganik perlakuan D (urea $25 \mathrm{~kg} \mathrm{ha}^{-1}$, SP-36 $30 \mathrm{~kg} \mathrm{ha}^{-1}, \mathrm{KCl} 25 \mathrm{~kg} \mathrm{ha}^{-1}$, Organonitrofos $1.000 \mathrm{~kg} \mathrm{ha}^{-1}$ ) yang berbeda nyata dengan perlakuan A, B, E, dan F, tetapi tidak berbeda nyata dengan perlakuan C (urea 37,5 $\mathrm{kg} \mathrm{ha}^{-1}$, SP-36 45 $\mathrm{kg} \mathrm{ha}^{-1}, \mathrm{KCl} 37,5 \mathrm{~kg} \mathrm{ha}^{-1}, 500$ Organonitrofos $\mathrm{kg} \mathrm{ha}^{-1}$ ) (Tabel 2). Peningkatan bobot berangkasan kering tanaman pada perlakuan kombinasi disebabkan karena dipengaruhi oleh serapan hara tanaman, dimana hara tersebut akan mempengaruhi pertumbuhan tanaman. Dengan adanya pupuk Organonitrofos serta ditambahkan pupuk urea yang keduanya mengandung unsur $\mathrm{N}$ menyebabkan bobot berangkasan tanaman lebih baik dibandingkan dengan aplikasi pupuk anorganik tunggal maupun pupuk Organonitrofos tunggal. Septima (2013) menyatakan aplikasi pemupukan urea $100 \mathrm{~kg}$ $\mathrm{ha}^{-1}$, SP-36 $50 \mathrm{~kg} \mathrm{ha}^{-1}, \mathrm{KCl} 100 \mathrm{~kg} \mathrm{ha}^{-1}, 2.000$
Organonitrofos $\mathrm{kg} \mathrm{ha}^{-1}$ ) memberikan hasil positif terhadap bobot berangkasan tanaman jagung.

Pada variabel pengamatan jumlah polong tanaman kacang hijau, perlakuan urea $25 \mathrm{~kg} \mathrm{ha}^{-1}$, SP-36 $30 \mathrm{~kg}$ $\mathrm{ha}^{-1}, \mathrm{KCl} 25 \mathrm{~kg} \mathrm{ha}^{-1}$, Organonitrofos $1.000 \mathrm{~kg} \mathrm{ha}^{-1}$ menunjukkan jumlah polong terbanyak sebesar 11,0 polong $\tan ^{-1}$ yang tidak berbeda nyata dengan perlakuan urea $37,5 \mathrm{~kg} \mathrm{ha}^{-1}, \mathrm{SP}-3645 \mathrm{~kg} \mathrm{ha}^{-1}, \mathrm{KCl} 37,5 \mathrm{~kg}$ $\mathrm{ha}^{-1}, 500$ Organonitrofos $\mathrm{kg} \mathrm{ha}^{-1}$, tetapi berbeda nyata dengan perlakuan rekomendasi dan tanpa pupuk (Tabel 2). Perbedaan dosis kombinasi pupuk yang diberikan menjadi faktor utama dalam mempengaruhi jumlah polong tanaman. Kombinasi pupuk yang tepat akan menunjukkan peningkatan jumlah polong yang lebih baik daripada kombinasi lainnya. Hal ini sejalan dengan penelitian Kurniadi, dkk., (2013) bahwa jumlah polong terbesar terdapat pada kombinasi pupuk rekomendasi (75 kg ha ${ }^{-1}$ urea, $100 \mathrm{~kg} \mathrm{ha}^{-1}$ SP-36, dan $100 \mathrm{~kg} \mathrm{ha}^{-1}$ $\mathrm{KCl}$ ) dengan $15 \mathrm{t} \mathrm{ha}^{-1}$ pupuk kandang ayam yaitu 239,7 polong plot $^{-1}$ yang disebabkan kombinasi tersebut telah dapat memenuhi ketersediaan unsur hara pada tanah. Sedangkan jumlah polong terendah dihasilkan pada perlakuan pupuk rekomendasi tunggal yaitu 115,3 polong plot $^{-1}$ yang disebabkan belum dapat menunjukkan ketersediaan unsur hara.

Penambahan dosis pupuk Organonitrofos yang diikuti dengan pengurangan dosis pupuk anorganik dan diaplikasikan secara komposit terbukti dapat 
Tabel 1. Pengaruh pupuk Organonitrofos dan kombinasinya dengan pupuk anorganik terhadap tinggi tanaman kacang hijau.

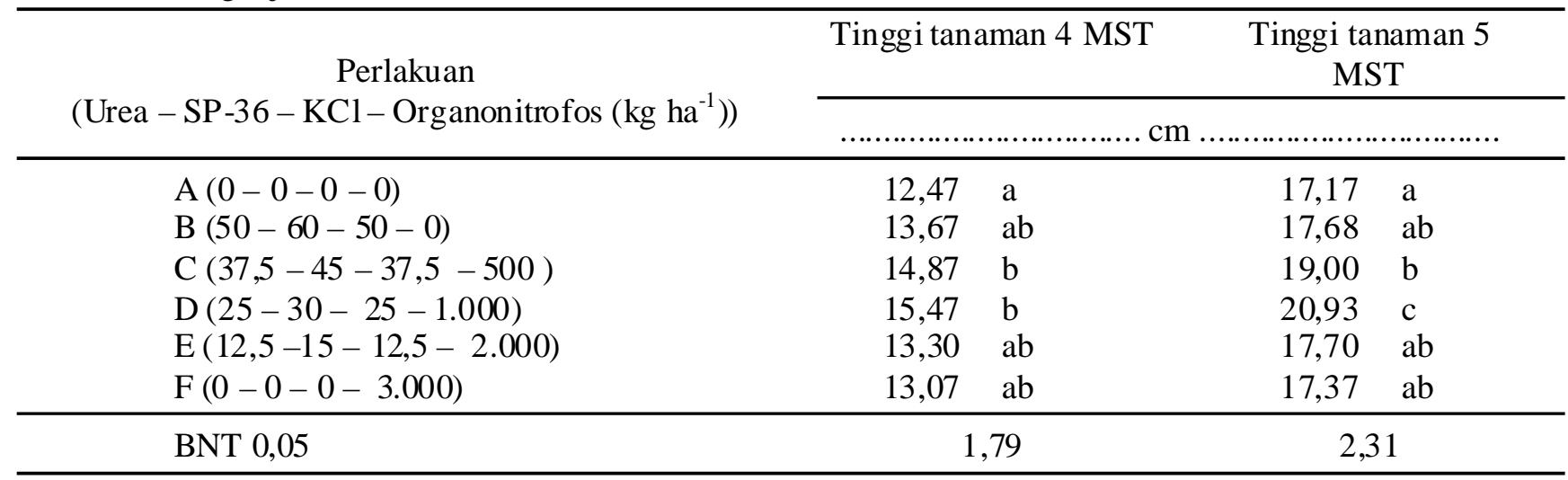

Keterangan: Angka yang diikuti dengan huruf yang sama tidak berbeda nyata pada taraf $5 \%$.

Tabel 2. Pengaruh pupuk Organonitrofos dan kombinasinya dengan pupuk anorganik terhadap jumlah polong, bobot berangasan, dan produksi kacang hijau.

\begin{tabular}{|c|c|c|c|c|}
\hline $\begin{array}{c}\text { Perlakuan } \\
\left.\text { (Urea }- \text { SP-36- } \mathrm{KCl}-\text { Organonitrofos }\left(\mathrm{Kg} \mathrm{ha}^{-1}\right)\right)\end{array}$ & $\begin{array}{l}\text { Jumlah polong } \\
\left(\text { polong } \tan ^{-1}\right)\end{array}$ & $\begin{array}{l}\text { Bobot berangkasan } \\
\qquad\left(\mathrm{kg} \mathrm{ha}^{-1}\right)\end{array}$ & $\begin{array}{r}\text { Produ } \\
\quad(\mathrm{kg}\end{array}$ & $\begin{array}{l}\text { si biji } \\
\left.a^{-1}\right)\end{array}$ \\
\hline $\mathrm{A}(0-0-0-0)$ & 7,4 & 644,4 & 244,4 & a \\
\hline $\mathrm{B}(50-60-50-0)$ & 9,3 & $761,1 \mathrm{ab}$ & 265,2 & $a b$ \\
\hline$C(37,5-45-37,5-500)$ & $10,2 \mathrm{bc}$ & $1.011,1$ bc & 293,3 & c \\
\hline $\mathrm{D}(25-30-25-1.000)$ & $11,0 \mathrm{c}$ & $1.022,2$ & 332,9 & $\mathrm{~d}$ \\
\hline $\mathrm{E}(12,5-15-12,5-2.000)$ & $9,1 \quad b$ & $738,9 \mathrm{ab}$ & 279,8 & $\mathrm{bc}$ \\
\hline $\mathrm{F}(0-0-0-3.000)$ & $8,2 \quad a b$ & $666,7 \mathrm{ab}$ & 255,8 & $\mathrm{a}$ \\
\hline BNT 0,05 & 1,5 & 355,38 & \multicolumn{2}{|c|}{23,5} \\
\hline
\end{tabular}

Keterangan: Angka yang diikuti dengan huruf yang sama tidak berbeda nyata pada taraf $5 \%$.

meningkatkan produksi tanaman kacang hijau. Hal ini terlihat pada perlakuan D (urea $25 \mathrm{~kg} \mathrm{ha}^{-1}, \mathrm{SP}-3630 \mathrm{~kg}$ $\mathrm{ha}^{-1}, \mathrm{KCl} 25 \mathrm{~kg} \mathrm{ha}^{-1}$, Organonitrofos $1.000 \mathrm{~kg} \mathrm{ha}^{-1}$ ) yang berbeda nyata terhadap tanpa pupuk (Tabel 2). Hal ini dipengaruhi oleh pupuk anorganik dan organik yang dikombinasikan memiliki kandungan unsur hara yang lebih lengkap dan mencukupi dibandingkan dengan pupuk anorganik maupun pupuk Organonitrofos saja. Sejalan dengan penelitian Maulidia (2013) bahwa kombinasi pemupukan $100 \mathrm{~kg} \mathrm{ha}^{-1}$ urea, $100 \mathrm{~kg} \mathrm{ha}^{-1} \mathrm{SP}-$ $36,200 \mathrm{~kg} \mathrm{ha}^{-1} \mathrm{KCl}, 1.000 \mathrm{~kg} \mathrm{ha}^{-1}$ Organonitrofos mampu melampaui produksi pada dosis anjuran pupuk anorganik sebesar $200 \mathrm{~kg} \mathrm{ha}^{-1}$ urea, $300 \mathrm{~kg} \mathrm{ha}^{-1}$ SP-36, $400 \mathrm{~kg}$ $\mathrm{ha}^{-1} \mathrm{KCl}$.

Pada fase vegetatif kombinasi perlakuan $\mathrm{D}$ (urea $25 \mathrm{~kg} \mathrm{ha}^{-1}$, SP-36 $30 \mathrm{~kg} \mathrm{ha}^{-1}, \mathrm{KCl} 25 \mathrm{~kg} \mathrm{ha}^{-1}$, Organonitrofos $1.000 \mathrm{~kg} \mathrm{ha}^{-1}$ ) menghasilkan tinggi tanaman kacang hijau tertinggi sebesar $20,93 \mathrm{~cm}$. Selain itu, perlakuan ini juga menghasilkan nilai lebih baik pada fase generatif yang meliputi bobot berangkasan, jumlah polong, dan produksi kacang hijau dengan perbandingan terhadap kontrol berturut-turut sebesar 3,6 polong $\tan ^{-1}$, $377,8 \mathrm{~kg} \mathrm{ha}^{-1}$, dan $88,5 \mathrm{~kg} \mathrm{ha}^{-1}$.

Hasil penelitian menunjukkan bahwa kombinasi pupuk Organonitrofos dengan pupuk anorganik pada perlakuan D (urea $25 \mathrm{~kg} \mathrm{ha}^{-1}, \mathrm{SP}-3630 \mathrm{~kg} \mathrm{ha}^{-1}, \mathrm{KCl} 25$ $\mathrm{kg} \mathrm{ha}^{-1}$, Organonitrofos $1.000 \mathrm{~kg} \mathrm{ha}^{-1}$ ) menghasilkan serapan N P tertinggi namun tidak berbeda nyata terhadap perlakuan C (urea 37,5 kg ha-1, SP-36 $45 \mathrm{~kg}$ ha $^{-1}, \mathrm{KCl} 37,5 \mathrm{~kg} \mathrm{ha}^{-1}, 500$ Organonitrofos $\left.\mathrm{kg} \mathrm{ha}^{-1}\right)$. Sedangkan pada serapan N P biji perlakuan D (urea 25 $\mathrm{kg} \mathrm{ha}^{-1}, \mathrm{SP}-3630 \mathrm{~kg} \mathrm{ha}^{-1}, \mathrm{KCl} 25 \mathrm{~kg} \mathrm{ha}^{-1}$, Organonitrofos $1.000 \mathrm{~kg} \mathrm{ha}^{-1}$ ) berbeda nyata dibandingkan perlakuan lainnya (Tabel 3). Hal ini diduga pada perlakuan D memiliki unsur hara $\mathrm{N}$ yang lebih banyak dari pada perlakuan lainnya sehingga keberadaannya dapat 
menunjang pertumbuhan maupun perkembangan tanaman. Sedangkan pada perlakuan $\mathrm{C}$ unsur hara $\mathrm{N}$ yang tersedia sebagian besar telah terserap pada fase pertumbuhan tanaman.

Hasil penelitian menunjukkan bahwa kombinasi pupuk Organonitrofos dengan pupuk anorganik menghasilkan serapan $\mathrm{K}$ tanaman tertinggi pada perlakuan D (urea $25 \mathrm{~kg} \mathrm{ha}^{-1}, \mathrm{SP}-3630 \mathrm{~kg} \mathrm{ha}^{-1}, \mathrm{KCl} 25$ $\mathrm{kg} \mathrm{ha}^{-1}$, Organonitrofos $1.000 \mathrm{~kg} \mathrm{ha}^{-1}$ ) yang berbeda nyata dibandingkan dengan perlakuan pupuk rekomendasi dan tanpa pupuk (Tabel 3). Hal tersebut berkaitan dengan ketersediaan unsur hara $\mathrm{K}$ dalam tanah serta penambahan unsur hara ke dalam tanah sehingga unsur hara tersebut mampu mencukupi kebutuhan hara tanaman kacang hijau. Selain itu dipengaruhi juga oleh faktor lingkungan seperti iklim. Curah hujan yang tinggi pada lingkungan pertanaman dapat mengakibatkan ketersediaan unsur hara berkurang akibat aliran permukaan.

Ketersediaan unsur hara NPK berangkasan dan biji pada kombinasi pemupukan urea $25 \mathrm{~kg} \mathrm{ha}^{-1}$, SP-36 $30 \mathrm{~kg} \mathrm{ha}^{-1}, \mathrm{KCl} 25 \mathrm{~kg} \mathrm{ha}^{-1}$, Organonitrofos $1.000 \mathrm{~kg}$ $\mathrm{ha}^{-1}$ lebih baik dibandingkan perlakuan pupuk rekomendasi dengan perbandingan yaitu $\mathrm{N}$ berangkasan 9,48 $\mathrm{kg} \mathrm{ha}^{-1}$; $\mathrm{N}$ biji 4,1 $\mathrm{kg} \mathrm{ha}^{-1}$; P berangkasan $0,5 \mathrm{~kg}$ ha $^{-1} ; \mathrm{P}$ biji $0,18 \mathrm{~kg} \mathrm{ha}^{-1} ; \mathrm{K}$ berangkasan $8,08 \mathrm{~kg} \mathrm{ha}^{-1}$; dan $\mathrm{K}$ biji $0,49 \mathrm{~kg} \mathrm{ha}^{-1}$. Hal ini menunjukkan bahwa perlakuan ini memiliki kandungan unsur hara yang lebih lengkap dan lebih mencukupi secara kualitas maupun kuantitas untuk pertumbuhan dan perkembangan tanaman.

Relative Agronomic Effectiviness(RAE) merupakan suatu cara untuk mengetahui pengaruh kombinasi pemupukan terhadap peningkatan kesuburan

Tabel 3. Pengaruh pupuk Organonitrofos dan kombinasinya dengan pupuk anorganik terhadap serapan hara NPK tanaman dan biji kacang hijau.

\begin{tabular}{|c|c|c|c|c|c|c|}
\hline \multirow{2}{*}{ Perlakuan } & $\begin{array}{c}\mathrm{N} \\
\text { Berangkasan }\end{array}$ & $\begin{array}{c}\mathrm{N} \\
\mathrm{Biji}\end{array}$ & $\begin{array}{c}\mathrm{P} \\
\text { Berangkasan }\end{array}$ & $\begin{array}{c}\mathrm{P} \\
\mathrm{Biji}\end{array}$ & $\begin{array}{c}\mathrm{K} \\
\text { Berangkas an }\end{array}$ & $\begin{array}{c}\mathrm{K} \\
\mathrm{Biji}\end{array}$ \\
\hline & \multicolumn{6}{|c|}{ 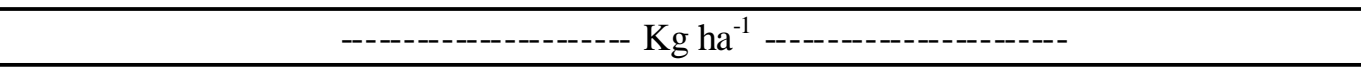 } \\
\hline A & 5,22 a & $27,73 \mathrm{a}$ & $0,63 \mathrm{a}$ & $1,68 \mathrm{a}$ & $10,26 \mathrm{a}$ & $8,24 \mathrm{a}$ \\
\hline B & $7,08 \mathrm{ab}$ & $30,00 \mathrm{~b}$ & $0,88 \mathrm{ab}$ & $1,87 \mathrm{~b}$ & $13,22 \mathrm{ab}$ & $9,29 \mathrm{~b}$ \\
\hline $\mathrm{C}$ & $15,87 \mathrm{~cd}$ & $31,28 \mathrm{~b}$ & $1,30 \mathrm{bc}$ & $1,90 \mathrm{~b}$ & $17,85 \mathrm{bc}$ & $9,90 \mathrm{c}$ \\
\hline $\mathrm{D}$ & $16,56 \mathrm{~d}$ & $34,10 \mathrm{c}$ & $1,38 \mathrm{c}$ & $2,05 \mathrm{c}$ & $21,03 \mathrm{c}$ & $9,78 \mathrm{c}$ \\
\hline $\mathrm{E}$ & $11,38 \mathrm{bc}$ & $30,12 \mathrm{~b}$ & $0,82 \mathrm{a}$ & $1,94 \mathrm{~b}$ & $12,98 \mathrm{ab}$ & $9,11 \mathrm{~b}$ \\
\hline $\mathrm{F}$ & $7,33 \mathrm{ab}$ & $30,09 \mathrm{~b}$ & $0,69 \mathrm{a}$ & $1,85 \mathrm{~b}$ & $11,38 \mathrm{ab}$ & $9,40 \mathrm{~b}$ \\
\hline BNT 0,05 & 5,152 & 1,46 & 0,43 & 0,09 & 6,47 & 0,44 \\
\hline
\end{tabular}

Keterangan: Angka yang diikuti dengan huruf yang sama tidak berbeda nyata pada taraf $5 \%$. $\mathrm{A}=$ Kontrol; $\mathrm{B}=$ urea $50 \mathrm{~kg} \mathrm{ha}^{-1}, \mathrm{SP}-3660 \mathrm{~kg} \mathrm{ha}^{-1}, \mathrm{KCl} 50 \mathrm{~kg} \mathrm{ha}^{-1} ; \mathrm{C}=$ urea $37,5 \mathrm{~kg} \mathrm{ha}^{-1}, \mathrm{SP}-3645 \mathrm{~kg} \mathrm{ha}^{-1}, \mathrm{KCl} 37,5$ $\mathrm{kg} \mathrm{ha}^{-1}$, Organonitrofos $500 \mathrm{~kg} \mathrm{ha}^{-1} ; \mathrm{D}=$ urea $25 \mathrm{~kg} \mathrm{ha}^{-1}$, SP-36 $30 \mathrm{~kg} \mathrm{ha}^{-1}$, KCl $25 \mathrm{~kg} \mathrm{ha}^{-1}$, Organonitrofos $1.000 \mathrm{~kg} \mathrm{ha}^{-1} ; \mathrm{E}=$ urea $12,5 \mathrm{~kg} \mathrm{ha}^{-1}, \mathrm{SP}-3615 \mathrm{~kg} \mathrm{ha}^{-1}, \mathrm{KCl} 12,5 \mathrm{~kg} \mathrm{ha}^{-1}$, Organonitrofos $2.000 \mathrm{~kg} \mathrm{ha}^{-1} ; \mathrm{F}=$ Organonitrofos $3.000 \mathrm{~kg} \mathrm{ha}^{-1}$.

Tabel 4. Hasil perhitungan Relative Agronomic Effectiviness (RAE) biomassa total.

\begin{tabular}{cccc}
\hline $\begin{array}{c}\text { Perlakuan } \\
\left(\text { Urea }- \text { SP-36 }-\mathrm{KCl}-\text { Organonitrofos }\left(\mathrm{Kg} \mathrm{ha}^{-1}\right)\right)\end{array}$ & $\begin{array}{c}\text { Bobot berangkasan } \\
\left(\mathrm{kg} \mathrm{ha}^{-1}\right)\end{array}$ & $\begin{array}{c}\text { Produksi biji } \\
\left(\mathrm{kg} \mathrm{ha}^{-1}\right)\end{array}$ & $\begin{array}{c}\text { Biomassa total } \\
(\%)\end{array}$ \\
\hline A $(0-0-0-0)$ & 644,4 & 244,4 & 0 \\
B $(50-60-50-0)$ & 761,1 & 265,2 & 100 \\
C $(37,5-45-37,5-500)$ & $1.011,1$ & 293,3 & 302 \\
D $(25-30-25-1.000)$ & $1.022,2$ & 332,9 & 339 \\
E $(12,5-15-12,5-2.000)$ & 738,9 & 279,8 & 94 \\
F $(0-0-0-3.000)$ & 666,7 & 255,8 & 24,5 \\
\hline
\end{tabular}


tanah, mutu tanaman, dan efisiensi penggunaan pupuk anorganik. Menurut Suswono (2011) kriteria lulus uji efektivitas pupuk organik secara agronomis yaitu pupuk yang diuji secara statistik sama dengan perlakuan standar atau mempunyai $\mathrm{RAE} \geq 100 \%$.

Berdasarkan hasil perhitungan RAE biomassa total yang diperoleh (Tabel 4), maka dapat diketahui bahwa pemberian kombinasi pupuk Organonitrofos dengan pupuk anorganik lebih efektif dibandingkan perlakuan pupuk rekomendasi. Hal ini terlihat dari setiap perlakuan kombinasi memberikan nilai RAE yang lebih tinggi daripada nilai RAE perlakuan rekomendasi. Perlakuan D (25 kg ha ${ }^{-1}$ urea, $30 \mathrm{~kg} \mathrm{ha}^{-1}$ SP-36, $25 \mathrm{~kg}$ ha $^{-1} \mathrm{KCl}, 1.000 \mathrm{~kg} \mathrm{ha}^{-1}$ Organonitrofos) menunjukkan nilai RAE biomasa total dengan perbandingan dengan perlakuan rekomendasi sebesar 239\%. Hasil ini menunjukkan bahwa pemberian pupuk Organonitrofos dan pupuk anorganik yang diaplikasikan secara komposit dapat digunakan sebagai alternatif pengganti pupuk rekomendasi budidaya kacang hijau. Hasil ini sejalan dengan penelitian Yupitasari (2013) bahwa kombinasi pupuk Organonitrofos dengan pupuk anorganik pada dosis $100 \mathrm{~kg}$ urea ha ${ }^{-1}, 50 \mathrm{~kg} \mathrm{SP}-36 \mathrm{ha}^{-1}, 50 \mathrm{~kg} \mathrm{KCl}$ $\mathrm{ha}^{-1}, 1.000 \mathrm{~kg}$ Organonitrofos ha-1 dapat digunakan sebagai pupuk alternatif pengganti pupuk kimia dalam budidaya tanaman tomat.

\section{KESIMPULAN}

Berdasarkan penelitian yang dilakukan perlakuan dengan dosis kombinasi $25 \mathrm{~kg} \mathrm{ha}^{-1}$ urea, $30 \mathrm{~kg} \mathrm{ha}^{-1}$ SP-36, $25 \mathrm{~kg} \mathrm{ha}^{-1} \mathrm{KCl}, 1000 \mathrm{~kg} \mathrm{ha}^{-1}$ Organonitrofos mampu meningkatkan pertumbuhan (tinggi tanaman), produksi (jumlah polong, bobot berangkas, produksi), serta serapan hara $\mathrm{N}, \mathrm{P}$, dan $\mathrm{K}$ tertinggi pada tanaman kacang hijau dan paling efektif terhadap biomasa total berdasarkan perhitungan Relative Agronomic Effectiveness dengan perbandingan terhadap pupuk rekomendasi sebesar $239 \%$.

\section{DAFTAR PUSTAKA}

Atman. 2007. Teknologi budidaya kacang hijau (Vigna radiata L.) di lahan sawah. Jurnal Ilmiah Tambua. IV (1): 89-95.

Balitkabi. 2012. Varietas Vima-1. Balitkabi.litbang. deptan.go.id/varietas-unggul/vu-kacang-hijau/ 105-vima-1.html. Diakses pada tanggal : 27 Desember 2012.
Biro Pusat Statistik. 2014. Luas Panen-ProduktivitasProduksi Tanaman Kacang Hijau Provinsi Lampung.http://www.bps.go.id/tnmn pgn.php?kat $=3$. Diakses pada tanggal : 19 Maret 2014.

Deviana, M. 2014. Uji efektivitas pupuk Oganonitropos dan kombinasinya dengan pupuk kimia terhadap pertumbuhan, produksi, serta serapan hara tanaman jagung (Zea mays L.) pada tanah Ultisol Gedung Meneng. (Skripsi). Bandar Lampung. $76 \mathrm{hlm}$.

Direktorat Budidaya Aneka Kacang dan Umbi. 2013. Prospek Pengembangan Agribisnis Kacang Hijau. Diakses pada tanggal : 16 Juli 2014. 93 hlm.

Kurniadi, P.F., H. Yetti., dan E. Anom. 2013. Peningkatan produksi kacang hijau (Vigna radiata $\mathrm{L}$.) dengan pemberian pupuk kandang ayam dan NPK Pertanian. Karya Ilmiah. Riau. $14 \mathrm{hlm}$.

Lingga, P. dan Marsono. 2001. Petunjuk Penggunaan Pupuk. Penebar Swadaya. Jakarta. $89 \mathrm{hlm}$.

Maulidia, O. R. 2013. Uji efektivitas pupuk Oganonitropos dan kombinasinya dengan pupuk kimia terhadap pertumbuhan, serapan hara, serta produksi tanaman ubi kayu. (Skripsi). Bandar Lampung. $87 \mathrm{hlm}$.

Mulyati, R. S., Tejowulan., dan V. A. Octarina. 2007. Respon tanaman tomat terhadap pemberian pupuk kandang ayam dan urea terhadappertumbuhan dan serapan N. J. Agroteksos. 17 (1): 51-56.

Nugroho, S.G., Dermiyati, J. Lumbanraja, S. Triyono, H. Ismono, M. K. Ningsih, dan F.Y. Saputri. 2013. Inoculation effect of N2-fixer and P-solubilizer into a mixture of fresh manure and phosphate rock formulated as Organonitrofos fertilizer on bacterial and fungal populations. J. Trop. Soils 18(1): $75-80$.

Nugroho, S.G., Dermiyati, J. Lumbanraja, S. Triyono, H. Ismono, H. Ismono, Y. Triolanda S., dan E. Ayuandari. 2012. Optimum ratio of fresh manure and grain size of phosphate rock mixture in a formulated compost for Organomineral NP fertilizer. J. Trop. Soils. 17 (2): 121-128.

Septima, A. R. 2013. Uji efektivitas pupuk Organonitrofos dan kombinasinya dengan pupuk kimia terhadap pertumbuhan, produksi serta 
serapan hara tanaman jagung (Zea mays .L). (Skripsi). Universitas Lampung. Bandar Lampung. $80 \mathrm{hlm}$.

Suswono. 2011. Metode Pengujian Efektivitas Pupuk Organik. Peraturan Menteri Pertanian Nomor 70/Permentan/SR. 140/2011.

Yupitasari, M. 2013. Pengaruh pupuk Organonitrofos dan kombinasinya dengan pupuk kimia terhadap pertumbuhan, serapan hara, dan produksi tanaman tomat (Lycopersicum esculentum) pada musim tanam kedua. Skripsi. $94 \mathrm{hlm}$.
Zebua, S. J., Toekidjo, dan R. Rabaniyah. 2012. Kualitas benih kacang hijau (Vigna radiata L.) R.Wilczek pada pertanaman monokultur dan tumpangsari dengan jagung (Zea mays L.). Vegetalika. 1 (4): 102-108. 